\title{
Penanaman Karakter Peduli Lingkungan Melalui Program Edukasi Konservasi Keanekaragaman Hayati Sejak Usia Dini
}

\author{
Nova Maulidina Ashuri ${ }^{1, *}$ | Noor Nailis Sa' adah ${ }^{1}$ | Edwin Setiawan ${ }^{1}$ | Dini Ermavitalini ${ }^{1}$ | Triono \\ Bagus Saputro $^{1}$ I Awik Puji Dyah Nurhayati ${ }^{1}$
}

${ }^{1}$ Departemen Biologi, Institut Teknologi Sepuluh Nopember, Surabaya, Indonesia

\section{Korespondensi}

*Nova Maulidina Ashuri, Departemen Biologi, Institut Teknologi Sepuluh Nopember, Surabaya, Indonesia. Alamat e-mail: maulidina@bio.its.ac.id

Alamat
Laboratorium Zoologi dan Rekayasa Hewan,
Departemen Biologi, Institut Teknologi
Sepuluh Nopember, Surabaya, Indonesia

\section{1 | PENDAHULUAN}

Ketergantungan masyarakat terhadap gadget (handphone) semakin meningkat beberapa tahun terakhir. Salah satunya dalam bidang pendidikan anak. Gadget (handphone) ini seringkali dijadikan alat bermain untuk mengalihkan perhatian anak di saat

\begin{abstract}
Abstrak
Program Pendidikan Konservasi Keanekaragaman Hayati sejak Usia Dini bertujuan untuk membangun karakter peduli lingkungan, menambah pengetahuan, minat, kepedulian dan kepedulian dalam melestarikan, melindungi dan memanfaatkan keanekaragaman hayati di sekitar lingkungannya yang dimulai sejak usia dini. Program pendidikan dilaksanakan dengan penyuluhan, simulasi iptek, dan advokasi (pendampingan). Program tersebut telah dilaksanakan di Taman Kanak-kanak Siti Masithoh dan di tempat pendidikan Al Qur'an yaitu Al Abror melalui pembuatan "Kebun Kehati" serta pelaksanaan seminar parenting dengan tema "Membangun Karakter Peduli Anak. Lingkungan Melalui Program Pelestarian Keanekaragaman Hayati Sejak Dini di Desa Boro, Kedungwaru, Tulungagung, Jawa Timur "yang dihadiri oleh siswa dan orang tua / wali siswa, perwakilan guru dari Taman Kanakkanak dan Sekolah Dasar di desa serta para pengawas dan Kepala Sekolah Dinas Pendidikan Pendidikan pelestarian keanekaragaman hayati ini juga dapat menambah pengetahuan dan inovasi generasi penerus untuk dapat memanfaatkan, mengelola, melindungi dan melestarikan sumber daya alam sekitar.Kegiatan ini juga dilakukan dalam rangka meningkatkan kesadaran setiap individu terhadap kondisi lingkungannya.Selain itu, keberhasilan program ini juga membutuhkan kendali dari masyarakat dan partisipasi negara.
\end{abstract}

\section{Kata Kunci:}

Keanekaragaman Hayati, Konservasi, Penanaman Karakter, Pendidikan, Usia Dini 
orang tua sedang bekerja. Hal ini banyak terjadi di lingkungan masyarakat baik di kota maupun di desa, termasuk pula anakanak usia dini. Anak yang terbiasa bermain gadget, akan memiliki kebiasaan perilaku bermain dengan lebih memilih bermain gadget (handphone) dari pada bermain di luar rumah. Kondisi ini tentu akan membawa kepedulian terhadap lingkungan pun juga menjadi berkurang. Di sisi lain, anak adalah calon generasi penerus bangsa yang perlu memiliki karakter salah satunya adalah peduli terhadap lingkungan sehingga dapat mengetahui segala macam sumber daya alam beserta keanekaragaman sumber daya hayatinya untuk bisa dimanfaatkan dalam memenuhi kebutuhan masyarakat secara berkelanjutan.

Kerugian akan dialami manusia itu sendiri, terlebih bagi generasi muda yang akan datang, apabila menusia melakukan eksploitasi sumber daya alam yang berlebihan dan ketidakramahan manusia terhadap lingkungan. Karakter manusia yang cenderung tidak mudah puas dan egois harus segera diubah menjadi karakter yang lebih peduli kepada lingkungan. Tidak mudah untuk merubah karakter seseorang, karena butuh waktu, pembiasaan sikap dan tingkah laku, dan proses yang cukup panjang. Namun, dengan metode yang tepat dan dimulai sedini mungkin, tidak menutup kemungkinan untuk menanamkan karakter yang baik terhadap seseorang. Salah satu karakter yang urgen untuk ditanamkan yaitu karakter peduli lingkungan. Penanaman karakter peduli lingkungan dapat dilakukan melalui pendidikan sejak anak masih usia dini, dimana pendidikan karakter peduli lingkungan adalah upaya penanaman nilai-nilai karakter kepada anak didik berupa sikap peduli terhadap lingkungan agar tercipta pola pikir dan perilaku sehari-hari yang ramah lingkungan (sustainable living) [1]

Rentangan anak usia dini menurut Pasal 28 UU Sisdiknas No.20/2003 ayat 1 adalah 0-6 tahun. Pendidikan anak usia dini merupakan upaya untuk menstimulasi, membimbing, mengasuh dan pemberian kegiatan pembelajaran yang akan menghasilkan kemampuan dan ketrampilan anak. Anak usia dini merupakan masa yang tepat dalam pendidikan yang menitik beratkan pada peletakan dasar ke arah pertumbuhan dan perkembangan fisik (koordinasi motorik halus dan kasar), bahasa, sosial-emosional, konsep diri, seni, moral, dan kecerdasan spiritual. Para pakar pendidikan anak juga menggolongkan anak usia 2-6 tahun sebagai fase realisme fantasia atau fase pra-operasional. Fase dimulai dengan penguasaan bahasa yang sistematis, permainan simbolis yang menunjukkan bahwa anak sudah mampu melakukan tingkah laku simbolis. Pada usia ini anak juga berpikir secara egosentris dan belum mampu secara perseptual, emosional-motivasional serta konseptual untuk menerjemahkan pengetahuan yang dimilikinya ke dalam aktivitas lainnya ${ }^{[2]}$. Anak pada usia ini dapat melanjutkan seluruh kehidupan mereka belajar tentang fenomena alam dan konservasi hutan dengan keterlibatan aktif mereka dalam kehidupan sekolah sehingga bisa mencapai pengalaman praktis dan teoritis di tahap ini ${ }^{3}$.

Kegiatan pengabdian kepada masyarakat berupa Program Edukasi Konservasi Keanekaragaman Hayati Sejak Usia Dini bertujuan untuk penanaman karakter peduli lingkungan, menambah pengetahuan, minat, kesadaran dan kepedulian dalam melestarikan, melindungi dan memanfaatkan keanekaragaman hayati di sekitar lingkungannya yang dimulai sejak usia dini. Manfaat yang diharapkan dari kegiatan pengabdian masyarakat ini antara lain dapat dijadikan sebagai alternative teknik pelaksaan kegiatan belajar mengajar dalam kurikulum pendidikan anak usia dini. Selain itu, dampak yang diharapkan dari kegiatan pengabdian masyarakat ini adalah a) terpeliharanya keanekaragaman hayati dan b) tertanamnya karakter peduli lingkungan pada anak-anak.

\section{2 | METODE PENGABDIAN}

\section{1 | Waktu dan Tempat Pengabdian}

Kegiatan ini dilaksanakan pada tanggal 6 April-3 Agustus 2018. Khusus pelaksanaan Seminar Parenting dialksanakanpada tanggal 3 Agustus 2018 pukul 08.00 - 12.00 WIB.Kegiatan pengabdian masyarakat dilakukan di TK Siti Masithoh di Desa Boro, Kecamatan Kedungwaru, Kabupaten Tulungagung, Jawa Timur.

\section{2 | Metode dan Rancangan Pengabdian}

Metode dalam penanaman karakter atau pembentukan kepribadian pada anak merujuk pada metode pendidikan Islam yang terdiri dari fikrah (konsep), thariqah (metode), uslub (teknis) dan sarana. Adapun Konsep pendidikan Islam terkait dengan tujuan pendidikan yaitu terbentuknya kepribadian Islam, terkait landasan kurikulum yang dibangun wajib berlandaskan aqidah Islam dengan tahapan yang sesuai dengan tahapan usia anak berdasarkan syari' ah Islam ${ }^{4}$. Selanjutnya metode yang dilakukan dalam pengabdian ini adalah seruan pemikiran dari narasumber dalam hal ini tim pengabdi dan penerimaan pemikiran dari guru, 
wali murid, dan murid. Dalam hal ini akan terjadi transfer pengetahuan melalui proses berpikir yang melibatkan akal untuk memahami proses belajar mengajar (Gambar 1).

Berdasarkan metode tersebut, teknis atau rancangan kegiatan yang akan dilakukan dalam pengabdian masyarakat ini adalah:

- Tahap Penentuan Target

Target pelaksanaan pengabdian ini adalah 1) penyediaan kebun kehati sebagai sarana pembelajaran, 2) pelaksaan seminar parenting untuk memberikan pemahaman kepada guru dan wali siswa untuk berperan aktif dalam pembentukan karakter anak serta 3) penanaman karakter peduli lingkungan pada siswa usia dini (3-6 tahun) yang ditunjukkan dengan kemampuannya dalam mengamati berbagai jenis tumbuhan yang ada di kebun kehati dan menuangkannya dalam kertas gambar serta kemauan dan kemampuannya dalam mengikuti instruksi dalam melakukan penanaman benih tanaman, penyiraman dan perawatan.

- Tahap Perencanaan

Kegiatan perencanaan dilakukan dengan melakukan koordinasi, penyampaian target dan tujuan pelaksaan pengabdian masyarakat kepada guru pembimbing di TK Siti Masithoh. Selanjutnya pelaksanaan diskusi untuk menentukan lokasi, desain, dan jenis-jenis tanaman yang akan ditanam di kebun kehati. Selanjutnya melakukan proses periizinan dengan pemilik yayasan dan penentuan waktu pelaksaan seminar parenting.

- Tahap Pelaksanaan

Pelaksanaan target 1) dilakukan setelah koordinasi dengan guru dan perizinan dari pemilik yayasan dengan pengolahan lahan, pembelian bahan pembuatan kebun, pembelian bibit tanaman dan melakukan penanaman sesuai dengan desain yang telah disepakati. Pelaksaan target 2) dilakukan dengan seminar parenting dengan mengundang perwakilan guru dari TK, RA, SD, MI di desa Boro, kepala dan perwakilan pengawas di Dinas Pendidikan Kecamatan Kedungwaru serta seluruh wali murid TK Siti Masithoh Boro. Pelaksaan target 3) dilakukan dengan mengajak para siswa menanam bibit tanaman di kebun kehati, mengamati berbagai jenis tanaman yang berwarna-warni, dan berbagai macam bentuk, mengajak mereka untuk mewarnai dan menggambar berbagai jenis tanaman yang telah mereka lihat, serta menyebutkan berbagai jenis tanaman atau hewan yang mereka lihat di kebun kehati serta manfaatnya.

\section{3 | HASIL PENGABDIAN DAN PEMBAHASAN}

Perkembangan teknologi beberapa kurun waktu terakhir mengalami perkembangan yang sangat pesat. Salah satu produk teknologi tersebut adalah handphone. Sudah menjadi pemandangan umum bahwa anak-anak sekolah bahkan anak usia dini sudah terbiasa menggunakan handphone untuk bermain. Tidak salah apabila hasil teknologi ini digunakan dalam kegiatan pembelajaran di sekolah. Namun demikian, dalam ilmu biologi, khususnya perkembangan tubuh manusia, usia tersebut merupakan saat dimana perkembangan sel-sel tubuh khususnya sel-sel syaraf mulai terbentuk. Ketika anak bermain game di handphone hanya organ mata, jari-jari tangan dan otak yang bekerja aktif sedangkan apabila anak-anak melakukan aktivitas bermain seperti di kebun, lapangan atau lingkungan di sekitarnya, maka seluruh organ indra tubuhnya akan bekerja secara aktif, baik mata, hidung, lidah, telinga, indra peraba di tangan dan kaki, serta otak akan bekerja sangat aktif mengenal benda-benda di sekitarnya dan apa saja yang dapat mereka mainkan dari benda-benda yang mereka temui.

Kondisi dan fakta pendidikan anak di usia dini seperti yang tersebut di atas menjadi latar belakang pengabdi untuk melakukan kegiatan pengabdian kepada masyarakat berupa Program Edukasi Konservasi Keanekaragaman Hayati Sejak Usia Dini melalui metode penerapan Konsep Pendidikan Islam yakni pembentukan kepribadian Islam pada anak didik yang dibangun berlandaskan aqidah Islam ${ }^{4}$. Konsep ini tentu dengan menyesuaikan tahapan usia anak berdasarkan syari' ah Islam. Konsep ini juga dilengkapi dengan metode yang khas, yaitu dengan tranfer pemikiran dari narasumber (dalam hal ini tim pengabdi) dan penerimaan pemikiran dari guru, wali murid, dan murid.

Kegiatan pengabdian ini dilaksanakan melalui tahapan penentuan target, perencaan dan pelaksanaan. Hasil dari pelaksanaan pengabdian ini dituliskan dalam tiga target sebagai berikut: 


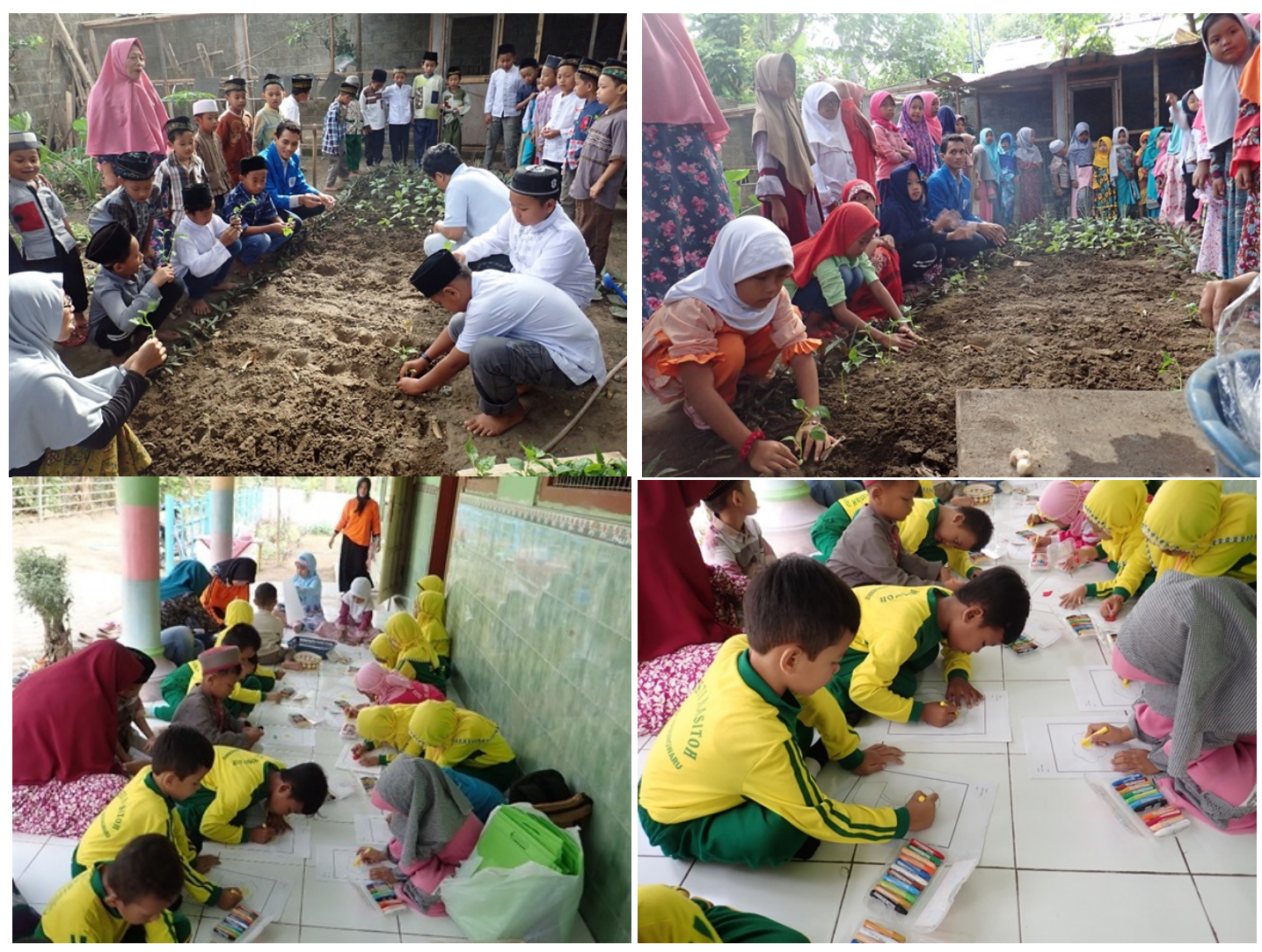

Gambar 1 Dokumentasi kegiatan menanam bersama serta mewarnai dan menggambar di "Kebun Kehati TK Siti Masithoh"

\section{1 | Kebun Keanekaragaman Hayati}

Keanekaragaman hayati atau biodiversitas merupakan semua bentuk kehidupan, yang secara ilmiah dapat dikelompokkan menurut skala organisasi biologisnya, meliputi gen, spesies tumbuhan dan hewan, mikroorganisme serta ekosistem dan proses-proses ekologi dimana bentuk kehidupan ini merupakan bagian di dalamnya. Disamping itu juga diartikan sebagai kondisi keanekaragaman bentuk kehidupan dalam ekosistem atau bioma tertentu. Keanekaragaman hayati seringkali digunakan sebagai ukuran kesehatan sistem biologis. Seiring dengan semakin meningkatnya jumlah penduduk, kawasan-kawasan yang secara alami menjadi habitat berbagai keanekaragaman hayati sering kali mengalami ancaman, antara lain adanya perubahan fungsi lahan menjadi kawasan industri atau pemukiman. Selain itu, penebangan pohon dan pembuangan limbah sembarangan juga dapat menyebabkan berkurangnya keanekargaaman hayati. Oleh karena itu, perlu adanya penanaman karakter peduli lingkungan melalui pendidikan mengenai konservasi keanekaragaman hayati sejak usia dini. Salah satu bentuk kegiatan ini adalah membuat kebun yang berisi berbagai jenis tanaman.

Pembuatan kebun ini dimulai dengan melakukan koordinasi dengan guru dan pemilik yayasan untuk memberikan izin untuk mengolah lahan kosong di samping bangunan sekolah TK Siti Masihoh Boro menjadi "Kebun Keanekaragaman Hayati (Kebun Kehati)" (Gambar 2). Kegiatan ini dilaksanakan pada tanggal 6 Mei 2018. Selanjutnya kegiatan dengan pembelian alat dan bahan pembuatan kebun berupa bambu, cangkul, dan lainnya. Lahan kosong di samping sekolah tersebut kemudian dibersihkan dan diolah agar dapat ditanami dengan berbagai jenis tumbuhan. Setelah itu juga dilakukan pembelian bibit tanaman berupa tanaman pangan, tanaman sayur, buah, tanaman berbunga, dan sebagainya. Setelah itu penanaman dilakukan sesuai dengan desain yang telah disepakati.

Kebun ini dapat dijadikan sebagai sarana untuk pertumbuhan dan perkembangan fisik (koordinasi motorik halus dan kasar) pada anak usia dini. Hal ini sesuai dengan penyataan Maimunah (2009) bahwa Pendidikan anak usia dini menitikberatkan pada peletakan dasar ke arah pertumbuhan dan perkembangan fisik (koordinasi motorik halus dan kasar), kecerdasan, daya cipta, 


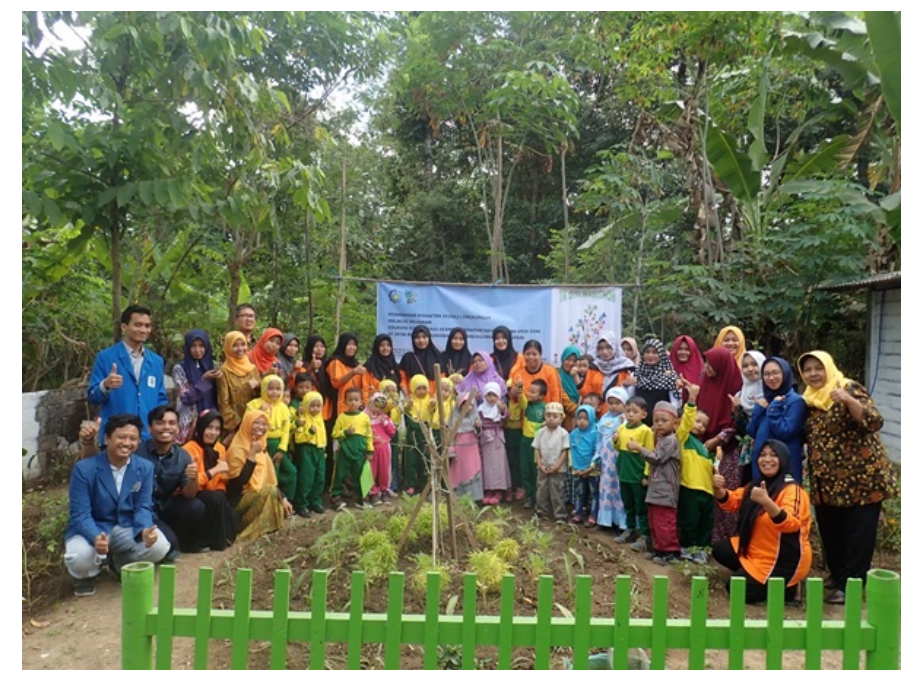

Gambar 2 Foto bersama peserta seminar parenting dengan tema edukasi konservasi keanekaragaman hayati sejak usia dini di "Kebun Kehati TK Siti Masithoh” Bersama dengan siswa TK dan tim pengabdi

kecerdasan emosi, dan kecerdasan spiritual ${ }^{[5]}$. Pendidikan anak usia dini merupakan upaya untuk menstimulasi, membimbing, mengasuh dan pemberian kegiatan pembelajaran yang akan menghasilkan kemampuan dan ketrampilan anak.

Kegiatan yang dapat dilakukan anak-anak di kebun ini antara lain belajar mengenal berbagai jenis tanaman melalui aktivitas membedakan bentuk dan warna bunga dan daun. Kebun ini juga bermanfaat bagi anak untuk meningkatkan ketelitian, ketepatan antara gerakan tangan dan mata, kesabaran, serta melatih jari-jari tangan [6]. Keberadaan kebun ini juga membantu guru untuk memberikan variasi dalam menggunakan media dalam pembelajaran.

Selain itu, Kebun kehati ini dapat dijadikan sebagai sarana untuk merealisasikan konsep dan menguatkan metode untuk membentuk kepribadian anak. Menurut Aghnaita, (2017) menjelaskaan dalam penelitiannya bahwa Pendidikan anak usia dini pada hakikatnya ialah pendidikan yang diselenggarakan dengan tujuan untuk memfasilitasi pertumbuhan dan perkembangan anak secara menyeluruh atau menekankan pada pengembangan seluruh aspek kepribadian anak ${ }^{11}$.

Perlu dipahami bahwa (kepribadian) pada setiap manusia terbentuk oleh pola pikir dan pola sikapnya. Pola pikir adalah cara yang digunakan untuk memikirkan sesuatu; yakni cara mengeluarkan keputusan hukum tentang sesuatu, berdasarkan kaidah tertentu yang diimani dan diyakini seseorang. Sedangkan pola sikap adalah cara yang digunakan seseorang untuk memenuhi tuntutan naluri dan kebutuhan jasmani; yakni upaya memenuhi tuntutan tersebut berdasarkan kaidah yang diimani dan diyakininya ${ }^{[7]}$.

Pola pikir akan terbentuk melalui proses berpikir. Fakta, indera, otak dan informsi sebelumnya merupakan empat unsur utama yang diperlukan dalam proses berpikir. Dengan demikian proses berpikir adalah proses mindahkan fakta ke otak melalui panca indera disertai informasi sebelumnya 4 [8]. Misalnya berpikir tentang bunga mawar, dalam kegiatan belajar mengajar anak usisa dini tetnang bunga mawar, anak diminta mencium baunya, melihat bentuk dan warnanya, meraba permukaan bunganya, apalagi diajak ke kebun bunga dan melihat bentuk batangnya, daunnya adan lain-lain. Maka kehadiran fakta tersebut dan indra anak saling bekerjasama dalam mengindra, anak akan jauh lebih dalam penginderaanya disbanding ketika hanya melihat gambar bunga mawar. Pengalaman pertama anak melihat bunga mawar menjadi informasi awal baginya dan akan digunakan ketika melihat kembali tentang bunga mawar dan menarasikannya sesuai informasi yang dia dapatkan sebelumnya. Apabila yang diterima anak hanya informasi teoritis saja yang dia hafal, maka anak akan menjadi pembelajar sakan, bukan pemikir. Oleh karena itu, keberadaan Kebun Kehati ini merupakan salah satu upaya menghadirkan fakta untuk anak didik.

Selanjutnya pola sikap juga harus diajarkan agar terbentuk kepribadian anak yang peduli lingkungan pada saat dewasa nanti. Kegiatan belajar mengajar dengan menggunakan sarana Kebun Kehati ini juga akan dapat membentuk pola sikap. Ketika anakanak diajak melihat fakta, para guru juga dapat menjelaskan fungsi dari tanaman-tanaman itu, diantaranya untuk memenuhi kebutuhan jasmani seperti makan, minum dan bernafas. Beberapa jenis tanaman ada yang dapat menghasilkan buah, umbi atau 


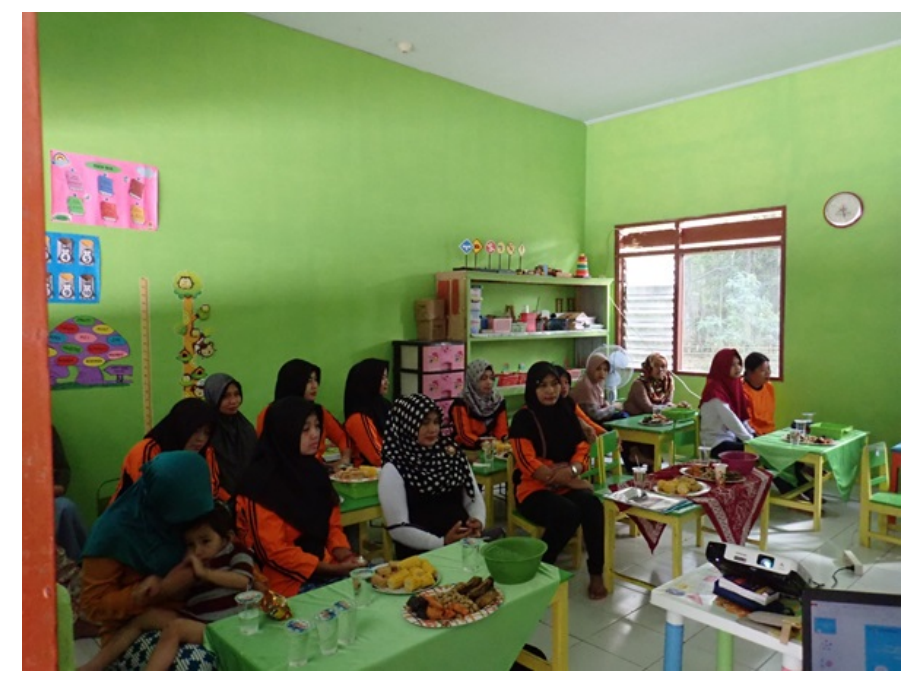

Gambar 3 Wali murid TK peserta sosialisasi parenting dengan tema "Edukasi Konservasi Keanekaragaman hayati sejak usia dini” di TK Siti Masithoh Desa Boro, Kedungwaru, Tulungagung, Jawa Timur”

bahan obat, kemudian akar tanaman yang dimiki oleh pepohonan juga dapat digunakan untuk menahan air dan daun-daun pada umbuhan dapat menghasilkan oksigen.

Apabila pemenuhan kebutuhan ini dilaksankan secara sempurna sesuai dengan keyakinannya, anak tersebut akan memiliki kepribadian yang mulia, dan teguh dalam mengarungi puncak kemuliaan, bahkan semakin tinggi, dari yang tinggi ke yang lebih tinggi lagi; dalam kondisi seperti ini, dia bisa menguasai kehidupan (dunia) dengan sesungguhnya, serta memperoleh kebahagian akhirat melalui segala usahanya ke sana, dengan keyakinan penuh ${ }^{[4]}$. Misalnya dalam keyakinan Islam, ketika menuju tahap kedewasaan, anak akan menyikapi berbagai kejadian dengan sikap yang benar dan tulus, memerintahkan yang makruf, dan mencegah yang munkar. Dimana beberapa keyakinan terkait pelestarian lingkungan diantaranya tertulis dalam Q.S. AlMu'minūn 23:19 (Lalu dengan air itu, Kami tumbuhkan untuk kamu kebun-kebun kurma dan anggur; di dalam kebun-kebun itu kamu peroleh buah-buahan yang banyak dan sebahagian dari buah-buahan itu kamu makan) yang mengindikasikan fungsi tumbuhan untuk menjaga keseimbangan ekosistem dan Hadist Rasulullah yang berisi tentang motivasi dan anjuran bagi mereka yang menghidupkannya maka ia menjadi pemilik tanah tersebut dan keyakinan bahwa siapa saja yang menebang pepohonan, maka Allah akan mencelupkannya ke dalam neraka.

Dengan informasi awal yang diperoleh mengenai berbagai manfaat tumbuhan untuk memenuhi kebutuhan hidunya yang dikaitkan dengan keyakinan yang dia miliki, maka akan terjadi proses berpikir dan pembentukan pemahaman dan pada akhirnya pola sikap atau perilaku yang terbentuk akan sesuai dengan keyakinan yang dimiliki.

\section{2 | Seminar Parenting dengan Tema Edukasi Konservasi Keanekaragaman Hayati Sejak Usia Dini}

Seminar parenting ini merupakan hasil kedua dari program pengabdian masyarakat Departemen Biologi ITS, Surabaya. Pada seminar parenting (Gambar 3) dengan mengundang perwakilan guru dari TK, RA, SD, MI di desa Boro, kepala dan perwakilan pengawas di Dinas Pendidikan Kecamatan Kedungwaru serta seluruh wali murid TK Siti Masithoh Boro dilakukan pada tanggal 3 Agustus 2018. Acara seminar tersebut dibuka oleh Dr.rer.nat. Edwin Setiawan, M.Sc. sebagai perwakilan dari LPPM-ITS. Selanjutnya sambutan disampaikan oleh KUPT Dinas, Banu M.Pd. pada kesempatan tersebut Banu menjelaskan bahwa anakanak sekolah sejak usia dini perlu diperkenalkan dengan berbagai sumber daya alam seperti polo pendem dan polo gantung yang memiliki potensi sebagai sumber pangan. Seminar ini dihadiri oleh para wali murid TK Siti Masithoh Boro, perwakilan dari SD, MI, TK dan PAUD di Desa Boro serta pengawas TK Kecamatan Kedungwaru, Kasilah, S.Pd. Selanjutnya dalam seminar tersebut disampaikan materi Edukasi Konservasi Keanekaragaman Hayati Sejak Usia Dini oleh ketua pelaksana.

Dalam seminar tersebut, dijelaskan bahwa kondisi masyarakat dalam beberapa tahun terakhir semakin bergantung pada teknologi. Ketika orang tua sibuk bekerja, dimana kewajiban mencari nafkah adalah tugas seorang ayah, seorang ibu yang 
memiliki kewajiban untuk mengurus rumah tangga dan mendidik anak pun ikut sibuk bekerja. Akibat kondisi tersebut, anak usia dini yang secara alami membutuhkan perhatian dari orang tua seringkali dialihkan perhatiannya dengan memberikan gadget. Permasalahan ini banyak terjadi di lingkungan masyarakat baik di kota maupun di desa. Ketika perilaku bermain anak telah mengalami gradasi dan menjadi suatu kebiasaan, anak-anak akan lebih memilih bermain dengan gadget (handphone) dari pada bermain di luar rumah. Selain itu, kepedulian terhadap lingkungan pun juga menjadi berkurang. Di sisi lain, anak adalah calon generasi penerus bangsa yang perlu memiliki karakter peduli terhadap lingkungan sehingga dapat mengetahui segala macam sumber daya alam beserta keanekaragaman sumber daya hayatinya untuk bisa dimanfaatkan dalam memenuhi kebutuhan masyarakat secara berkelanjutan.

Edukasi ini juga dikaitkan dengan perkembangan anak, berdasarkan usianya, perkembangan tersebut dapat dikelompokkan ke dalam 4 fase, usia 0-2 tahun merupakan fase penyusuan dimana anak perlu mendapatkan full ASI untuk perkembangan dan membentuk daya imunitas tubuh anak; usia 2-6 tahun adalah fase pembiasaan untuk terikat peraturan hidup sesuai dengan akidahnya, orang tua memberi contoh perbuatan yang sesuai akidahnya dan bersifat tidak memaksa; usia 7-10 tahun merupakan fase pendisiplinan, orang tua memberikan pelatihan untuk terikat hukum dan aturan hidup sesuai dengan akidahnya, memberikan perintah ke anak namun apabila anak melanggar, anak tidak boleh dihukum, anak diberi pemahaman terkait kewajiaban sebagai laki-laki dan perempuan; dan usia 10-15 tahun adalah fase pendisiplinan lanjut, apabila anak melakukan pelanggaran, maka perlu diberi hukuman, pada fase ini merupakan fase duplikasi dari fase baligh, anak harus melaksanakan kewajiban seperti halnya orang dewasa yang telah baligh.

Pertambahan usia ini juga terkait erat dengan perkembangan emosi anak. Emosi anak perlu dibangun, tidak terlalu dipaksa untuk belajar yang berhubungan dengan kognitif. Jika emosi berkembang sempurna, maka perkembangan kognitif akan mengikuti. Kurikulum saat ini lebih banyak diisi dengan akal dan kognitif sehingga perlu ditambahkan dan lebih ditekankan materi terkait penananam karakter. Pada usia sekolah lebih ditekankan ke anak untuk dapat menjawab simpul permasalahan manusia ketika hidup di dunia yang dapat dijadikan sebagai tujuan pendidikan, seperti menyelesaikan permasalahan masyarakat dengan memanfaatkan keanekaragaman hayati secara berkelanjutan dan sesuai dengan keyakinannya.

Para orang tua wali antusias dalam mendengarkan penjelasan dari narasumber. Sesi diskusi juga berjalan dengan lancar, beberapa peserta mengajukan berbagai pertanyaan, seperti bagaimana agar siswa mau dan terbiasa membuang sampah pada tempanya, siswa malah lebih kreatif dengan menyimpan sampah di sela-sela meja belajarnya. Selanjutnya, terdapat pertanyaan bagaimana membiasakan siswa berkata sopan, padahal guru telah berupaya mengajarkan siswa TK untuk berkata sopan, namun tetap sulit memperbaiki perilaku tersebut.

Kejadian-kejadian yang ditanyakan tersebut sering dijumpai di sekolah-sekolah pada zaman milenial ini. Seperti yang telah dijelaskan sebelumnya, bahwa pola sikap merupakan salah satu unsur penting dalam membentuk kepribadian siswa. Namun demikian, pola sikap yang terbentuk dari proses berpikir menggunakan akal, belum dapat berfungsi maksimal. Akan akan dapat berfungsi maksimal apabila seseorang telah memasuki usia baligh. Pada usia dini, siswa masih berpikir secara egosentris dan belum mampu secara perseptual, emosional-motivasional serta konseptual untuk menerjemahkan pengetahuan yang dimilikinya ke dalam aktivitas lainnya ${ }^{[7}$. Sehingga pada usia ini kemampuan meniru lebih dominan. Sehingga nasehat yang diberikan oleh guru tidak mampu membentuk perilakunya. Anak akan berperilaku sesuai dengan apa yang dia lihat di lingkungan sekitarnya. Oleh karena itu, peran orang tua juga sangat penting dalam membentuk kepribadian seorang anak. Ketika para guru telah menyampaikan perilaku-perilaku yang baik, maka ketika di rumah, orang tua juga harus membiasakan perilaku sesuai dengan apa yang diajarkan guru.

Mendidik anak di zaman ini harus bisa mewujudkan kepribadian sesuai dengan keyakinan guru dan orang tua. Seringkali pendidikan yang ada di TK atau yang diberikan orang tua ketika di rumah (parenting) lebih focus ke uslub (teknis) dan sarana, namun abai dalam Konsep dan metode padahal kedua hal ini harus lebih dulu hadir dalam benak para pendidik sebab kedua hal ini bersifat pasti wajib hukumnya. Pola sikap anak akan terbentuk apabila dalam pendidikan diajarkan pengetahuan yang bisa membentuk pola pikir anak-anak dan pengetahuan itu diambil untuk menyelesaiakan masalahh kehidupan mereka lalu mereka diterapkan dalam perilaku kesehariannya, maka akan terbentuk pola sikap mereka ${ }^{[4]}$.

\section{3 | Bermain di Kebun dan Lomba Menggambar}

Pelaksaan pengabdian masyarakat yang ketiga adalah kegiatan bermain di Kebun Kehati dan Lomba Menggambar. Kegiatan ini dilaksanakan bersamaan dengan kegiatan Seminar yang dihadiri para Wali Murid pada tanggal 3 Agustus 2018. Dalam 


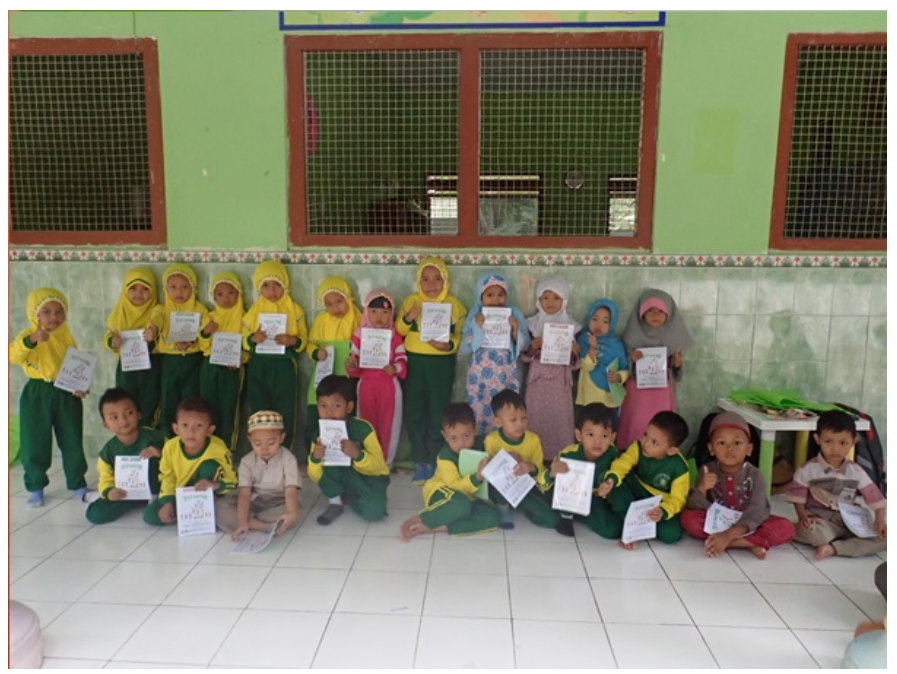

Gambar 4 Murid-murid TK Siti Masithoh Boro, yang telah selesai melakukan kegiatan mewarna

kegiatan ini, para siswa diajak berkeliling ke Kebun Kehati yang telah dibuat. Anak-anak diajarkan untuk mengenal berbagai jenis tanaman berbunga dengan berbagai bentuk dan warnanya, mencium berbagai aroma yang dihasilkan bunga tersebut, serta meraba permukan daun maupun batang bunganya. Kemudian dijelaskan juga jenis-jenis tanaman yang dapat digunakan untuk memenuhi kebutuhan dan dapat digunakan dalam kehidupan sehari-hari. Aktivitas ini dilakukan agar para siswa mengetahui fakta dengan mengoptimalkan seluruh saraf di panca indranya. Dengan demikian para siswa akan lebih mudah dalam mengingat informasi yang diperoleh. Dan tentunya memori tersebut dapat tersmpan lama sampai dewasa nanti.

Selanjutnya, para siswa juga diajak untuk mewarnai dan menggambar berbagai jenis tanaman yang telah mereka lihat (Gambar 4). Kegiatan ini juga merupakan slah satu teknik agak para siswa dapat mengenal dan mengingat berbagai macam keanekaragaman hayati yang terdapat di sekitarnya. Ketika para siswa sudah mengetahui fakta-faktanya, Kemudian para siswa dikenalkan manfaat dari masing-masing jenis hewan maupun tumbuhan tersebut. Apabila telah tahu manfaatnya, maka akal akan memproses bahwa berbagai jenis keanekaragaman tersebut penting dalam kehidupan sehari-harinya sehingga perlu untuk dilestarikan.

\section{4 | SINGKATAN DAN AKRONIM KEHATI (KEANEKARAGAMAN HAYATI)}

ASI (Air Susu Ibu), KUPT (Kepala Unit Pengelola Teknis), MI (Madrasah Ibtidaiyah), PAUD (Pendidikan Anak Usia Dini), QS (Qur' an Surat), SD (Sekolah Dasar), TK (Taman Kanak-Kanak).

\section{5 | KESIMPULAN}

Kegiatan ini dapat pula diaplikasikan di sekolah-sekolah lain mulai dari tingkat sekolah dasar dan menengah. Kegiatan pengabdian selanjutnya, sebaiknya juga melibatkan orang tua. Edukasi konservasi keanekaragaman hayati ini juga dapat menambah pengetahuan dan inovasi para generasi penerus bangsa untuk dapat memanfaatkan, mengelola, melindungi dan melestarikan sumber daya alam di sekitar mereka yang pada akhirnya dapat membantu mensejahteran masyarakat. Penanaman karakter peduli lingkungan melalui konservasi keanekaragaman hayati juga dilakukan dalam rangka meningkatkan kesadaran (awareness) setiap individu terhadap kondisi lingkungannya. Selain itu, kesuksesan program ini juga perlu adanya kontrol masyarakat dan peran serta negara. 


\section{6 | UCAPAN TERIMA KASIH}

Tim pengabdi mengucapkan banyak terima kasih kepada DRPM ITS, Departemen Biologi, Fakultas Sains-ITS, para guru TK Siti Masithoh Boro Kecamatan Kedungwaru, Tulungagung, Dinas Pendidikan Tulungagung dan semua pihak yang telah berkontribusi dalam terselenggaranya kegiatan pengabdian masyarakat ini.

\section{Referensi}

1. Aghnaita A. Perkembangan Fisik-Motorik Anak 4-5 Tahun Pada Permendikbud no. 137 Tahun 2014 (Kajian Konsep Perkembangan Anak). Al-Athfal: Jurnal Pendidikan Anak 2017;3(2):219-234.

2. Jayawardana H. Pendidikan Karakter Peduli Lingkungan Sejak Dini sebagai Upaya Mitigasi Bencana Ekologis. In: Symbion (Symposium on Biology Education); 2016. p. 49-64.

3. Bhuiyan MAH, Islam R, Siwar C, Ismail SM. Educational tourism and forest conservation: Diversification for child education. Procedia-Social and Behavioral Sciences 2010;7:19-23.

4. Tanjung Y. Strategi Mendidik Anak Zaman Now; In Seri Parenting Ideologis. Al Azhar Press; 2018.

5. Maimunah H, Pendidikan Anak Usia Dini. Yogyakarta. DIVA press; 2009.

6. Sari IP. Meningkatkan Keterampilan Motorik Halus Anak Melalui Kegiatan Kolase Pada Kelompok B Tk Dawungan I Masaran Sragen Tahun Pelajaran 2012/2013. PhD thesis, Universitas Muhammadiyah Surakarta; 2013.

7. Yasin. Pilar-pilar Pengokoh Nafsiyah Islamiyah. Pustaka Fikrul Islam; 2004.

8. Yusanto MI, et al. Menggagas Pendidikan Islami. Al Azhar Press; 2018.

Cara mengutip artikel ini: Nova Maulidina Ashuri, Noor Nailis Sa'adah, Edwin Setiawan, Dini Ermavitalini, Triono Bagus Saputro, Awik Puji Dyah Nurhayati, (2021), Penanaman Karakter Peduli Lingkungan Melalui Program Edukasi Konservasi Keanekaragaman Hayati Sejak Usia Dini, Sewagati: Jurnal Pengabdian Kepada Masyarakat, 5(3):240-248. 